\title{
The fate of germ cells in the testis of fetal Sex-reversed mice
}

\author{
Anne McLaren \\ M.R.C. Mammalian Development Unit, 4 Stephenson Way, London NWI 2HE, U.K.
}

\begin{abstract}
Summary. XX germ cells in the fetal testes of XX Sex-reversed male mice were observed mostly to develop in the same manner as do XY germ cells in a normal fetal testis; but some, in the vicinity of the mesonephric rete region, entered the prophase of meiosis at the same time as do XX germ cells in a normal fetal ovary. No germ cells in meiosis were found in the fetal testes of XY males, nor of XO Sex-reversed males. It is suggested that a second $\mathrm{X}$ chromosome renders a germ cell more susceptible to the meiosis-inducing influence of the mesonephric rete.
\end{abstract}

\section{Introduction}

In normal mouse development, as in human, $\mathrm{XX}$ germ cells in the ovary enter the prophase of meiosis well before birth. XY germ cells in the testis, on the other hand, enter a state of mitotic arrest as the female germ cells are entering meiosis, 13-15 days post coitum (p.c.), and resume mitotic proliferation in the immediate post-natal period. The first meiotic stages in the normal mouse testis are seen no earlier than 8-10 days after birth.

The fate of XX germ cells in a testis has long been a topic of interest and controversy. Sex-reversed $(S x r)$ is a dominant autosomal gene in the mouse that causes XX and XO embryos to develop as phenotypic males (Cattanach, Pollard \& Hawkes, 1971). According to Cattanach et al. (1971), the XX Sxr/+ germ cells resembled normal male germ cells during the fetal period, but degenerated a few days after birth, while the XO $S x r /+$ germ cells were able to undergo spermatogenesis and were present in the adult testis, although the spermatozoa that were formed were few in number and abnormal in morphology. More detailed study has shown that, while most of the XY germ cells degenerate in the neonatal period, the testes of some XX $S x r /+$ males contain small numbers of growing oocytes within the seminiferous tubules 1-2 weeks after birth (McLaren, 1980). It seems, therefore, that XX germ cells in a testis may have more than one developmental pathway open to them.

In XX/XY mouse chimaeras, most of which develop as males (McLaren, 1976), no XX germ cells have been found among the germ cell population undergoing spermatogenesis in post-natal life (Mystkowska \& Tarkowski, 1968), although they presumably enter the genital ridges with the XY germ cells. The finding by Mystkowska \& Tarkowski (1970) of meiotic germ cells in the fetal testes of such chimaeras suggested that these might be XX germ cells, entering meiosis autonomously according to their own developmental programme. This interpretation was supported by the study of McLaren, Chandley \& Kofman-Alfaro (1972), which showed first that the meiotic events in normal $\mathrm{XX}$ fetal ovary and $\mathrm{XX} / \mathrm{XY}$ chimaeric fetal testis were very similar in timing, and secondly that the meiotic germ cells in the fetal testis lacked the sex vesicle containing the precociously condensing XY bivalent, a characteristic of XY meiotic cells in the post-natal testis.

However, entry into meiosis is probably not an autonomous property of the germ cells themselves, but is probably induced by the adjacent mesonephric rete region, since meiotic stages 
are not seen in gonads developing in the absence of this region (Byskov, 1974). Byskov \& Saxen (1976) showed that germ cells in a cultured mouse gonad would enter meiosis if in the vicinity of a piece of rete, even if the two tissues were separated by a cell-impermeable filter, but not if the gonad was maintained in isolation. They therefore postulated that entry into meiosis was stimulated by a diffusible factor, termed Meiosis Inducing Substance (MIS), produced by the rete. A similar conclusion was reached by $O \&$ Baker (1976) for the hamster. Male and female germ cells could be induced to enter meiosis if exposed to MIS before the testis cords had formed. Byskov (1978) suggests that MIS is produced by both male and female rete tissue from about 13 days post coitum in the mouse, but in the normal testis the germ cells are already sequestered in testis cords by this time and do not respond to its influence.

An apparent contradiction exists between the view that the meiotic cells in the fetal $X X / X Y$ testis are $\mathrm{XX}$ rather than $\mathrm{XY}$ germ cells, entering meiosis before birth in accordance with their own genetic constitution, and the suggestion that entry into meiosis is determined by an external stimulus. On the latter view, the presence of meiotic cells within a testis cord might indicate some inadequacy in the $\mathrm{XX} / \mathrm{XY}$ cord structure, affecting $\mathrm{XX}$ and $\mathrm{XY}$ germ cells equally. The absence of a sex vesicle is suggestive rather than conclusive evidence that the affected germ cells are $\mathrm{XX}$ since Burgoyne (1978) has pointed out that an XY germ cell entering meiosis prenatally might not possess such a vesicle (but see Whitten, Beamer \& Byskov, 1979). It was also not clear why so few cells in the chimaeric testis had entered meiosis if they were the XX germ cells and were behaving autonomousiy, since the $\mathrm{XX}$ population would be expected on average to equal the $\mathrm{XY}$ population in number in chimaeric testes.

The XX $S x r /+$ fetal testis may be of particular value in resolving this contradiction, since it is populated only by $\mathrm{XX}$ germ cells, without the complicating presence of an XY cell population. The fetal material examined by Cattanach et al. (1971) was limited in extent, being confined to sections of the XX Sxr/+ testis on the 17 th day of gestation. The present paper describes a more extensive examination of the fetal testis of Sex-reversed mice, beginning at the time that $\mathrm{XX}$ germ cells enter meiosis in the ovary.

\section{Materials and Methods}

Male progeny of $\mathrm{Sxr} /+$ male mice were obtained from Dr B. M. Cattanach (M.R.C. Radiobiology Unit, Harwell, U.K.) and test-mated with females carrying the X-linked coat pattern marker Harlequin $(H q)$. Those males identified as $S x r /+$ by the appearance of at least one $\mathrm{X}^{\mathrm{Hq}} \mathrm{X}^{+}$male among their offspring were then mated to normal XX females of the randomly bred $\mathrm{Q}$ strain or to $\mathrm{XO}$ females from a stock originally derived from the Institute of Animal Genetics, Edinburgh. Females were inspected each morning for vaginal plugs. For purposes of dating the pregnancies, coitus was assumed to have taken place at the midpoint of the previous dark cycle, i.e. 14:00 h on the previous day as the stock was kept on a reversed light/dark regime. Pregnant females were killed, between 10:00 and 15:00 h, 14-19 days after the presumed day of coitus.

Embryos were dissected out of the uterus, and sexed by examination of the gonads under a dissecting microscope. Each gonad and its associated mesonephric rete region were fixed in Bouin's fluid, embedded and serially sectioned at $8 \mu \mathrm{m}$ by standard histological procedures, and stained with haematoxylin and eosin. In the second and third series of pregnancies each embryo was classified as sex chromatin-positive or -negative by means of the amnion-spreading technique described by Vickers (1967), and/or as having 39 or 40 chromosomes from air-dried spreads prepared from limb buds and tail by the methods of Evans, Burtenshaw \& Ford (1972). The genotype of each embryo could then be inferred (see Table 1). 
Table 1. Criteria for identification of embryo genotype in mouse litters segregating for $S x r$

\begin{tabular}{cccc}
\hline $\begin{array}{c}\text { Phenotypic } \\
\text { sex }\end{array}$ & $\begin{array}{c}\text { Sex } \\
\text { chromatin }\end{array}$ & $\begin{array}{c}\text { Chromosome } \\
\text { number }\end{array}$ & Genotype \\
\hline$q$ & + & 40 & XX $+/+$ \\
0 & - & 39 & XO +/+ \\
+ & - & 40 & XY $+/+$ or XY $S x r /+$ \\
0 & + & 40 & XX Sxr $/+$ \\
0 & - & 39 & XO $S x r /+$ \\
0 & & & \\
\hline
\end{tabular}

\section{Results}

Series 1 (Table 2)

In this series of pregnancies, the fetuses were sexed, but no further information as to their genotype was obtained. A third of the male fetuses would be expected on Mendelian grounds to be XX $S x r /+$.

The sectioned ovaries were examined to chart the entry of the germ cells into, and their progress through, the prophase of meiosis. At 14 days p.c. (PI. 1, Fig. 1), all ovaries showed some germ cells in leptotene, but many were still premeiotic. At 15 days p.c., many leptotene and zygotene stages were seen. By 16 days p.c. (Pl. 1, Fig. 2), virtually all the germ cells had entered meiosis, and the first pachytene stages were seen. At 17 and 18 days p.c., most of the germ cells were in pachytene, and many appeared to be atretic. At 19 days p.c., some diplotene stages were seen, and the somatic cells were beginning to group themselves into follicles around the oocytes.

Table 2. Presence of meiotic germ cells in mouse fetuses from $X X$ females mated to $S x r /+$ males (Series 1$)$

\begin{tabular}{|c|c|c|c|c|c|}
\hline \multirow[b]{2}{*}{$\begin{array}{l}\text { Stage of pregnancy } \\
\text { (days p.c.) }\end{array}$} & \multirow[b]{2}{*}{$\begin{array}{l}\text { No. of } \\
\text { litters }\end{array}$} & \multicolumn{2}{|c|}{ Male fetuses } & \multicolumn{2}{|c|}{ Female fetuses } \\
\hline & & $\begin{array}{l}\text { No. with meiotic } \\
\text { germ cells }\end{array}$ & Total & $\begin{array}{l}\text { No. with meiotic } \\
\text { germ cells }\end{array}$ & Total \\
\hline 14 & 3 & 1 & 18 & 16 & 16 \\
\hline 15 & 1 & 3 & 10 & 3 & 3 \\
\hline 16 & 1 & 2 & 7 & 3 & 3 \\
\hline 17 & 1 & 2 & 7 & 4 & 4 \\
\hline 18 & 1 & 1 & 6 & 7 & 7 \\
\hline 19 & 3 & 0 & 14 & 9 & 9 \\
\hline
\end{tabular}

Some of the testes were found to contain meiotic germ cells within the testis cords (P1. 1, Figs 3 and 5). These resembled in appearance the meiotic germ cells seen in ovaries of the same age. At 15,16 and 17 days p.c., about $25 \%$ of the male fetuses contained such germ cells, usually (although not always) in both testes. At 14 and 18 days p.c. only a single male fetus with meiotic germ cells was seen, and at 19 days p.c. none was found in 14 examined.

In this and later series, the spatial distribution of the meiotic germ cells in the testes was not random. They were always located in the cords at the side of the testis adjacent to the mesonephric rete region (Pl. 1, Figs 4 and 6). Almost always they were in the peripheral layer of cords on this side of the testis; occasionally the cord in which they were seen was separated from the mesonephric periphery of the testis by one other cord; they were never found in the half of the testis away from the rete region. 
The number of meiotic germ cells varied widely from one testis to another. In some, there were only one or two, in a single cord; in others, several hundred meiotic germ cells were seen, involving several cords. Even in such cases, however, the fraction of male germ cells in meiotic prophase was very small, and the remainder were typical prospermatogonia, indistinguishable from those in testes not containing any meiotic germ cells.

\section{Series 2 (Table 3)}

To check whether the meiotic germ cells were confined to XX $S x r /+$ fetuses, or also occurred in XY testes, genotype identifications were carried out on the fetuses of 5 litters, by means of amnion sex chromatin preparations, and/or chromosomal sexing. The genotype of the fetus was not known at the time that the testes were examined histologically. All the meiotic germ cells observed proved to be in testes of XX $S x r /+$ fetuses, although in 2 fetuses of this genotype no meiotic germ cells were found. The difference between $\mathrm{XX} S x r /+$ and $\mathrm{XY}$ fetuses is statistically significant $\left(\chi_{(1)}^{2}=19 \cdot 1, P<0.001\right)$.

Table 3. Presence of meiotic germ cells in male fetuses from $\mathrm{XX}$ females mated to $S x r /+$ males (Series 2)

\begin{tabular}{ccccccc}
\hline & & \multicolumn{2}{c}{ XX $S x r /+$ fetuses } & & \multicolumn{2}{c}{ XY fetuses } \\
\cline { 3 - 4 } \cline { 5 - 6 } $\begin{array}{c}\text { Stage of pregnancy } \\
\text { (days p.c.) }\end{array}$ & $\begin{array}{c}\text { No. of } \\
\text { litters }\end{array}$ & $\begin{array}{l}\text { No. with meiotic } \\
\text { germ cells }\end{array}$ & Total & & $\begin{array}{c}\text { No. with meiotic } \\
\text { germ cells }\end{array}$ & Total \\
\hline 16 & 3 & 4 & 5 & & 0 & 15 \\
17 & 2 & 2 & 3 & & 0 & 5 \\
\hline
\end{tabular}

\section{Series 3 (Table 4)}

The difference between $\mathrm{XY}$ and $\mathrm{XX}$ testes could reflect the number of $\mathrm{X}$ chromosomes in the genome, or the presence or absence of the $\mathrm{Y}$ chromosome. $\mathrm{S} x \mathrm{r} /+$ males were therefore mated to $\mathrm{XO}$ females, so that XO $S x r /+$ testes could be compared with $\mathrm{XY}$ and $\mathrm{XX}$ testes. The results were clear-cut: almost all the XX $S x r /+$ fetuses again contained some germ cells in meiosis, but no meiotic cells were seen in any of the $5 \mathrm{XO} S x r /+$ fetuses identified.

\section{PLATE 1}

Fig. 1. Ovary at 14 days p.c. Some germ cells are in prophase of meiosis (L, leptotene; $Z$, zygotene). $\times 990$.

Fig. 2. Ovary at 16 days p.c. All germ cells are in prophase of meiosis (zygotene, $\mathrm{Z}$, and early pachytene, P). $\times 990$.

Fig. 3. Testis of XX $S x r /+$ male fetus at 15 days p.c. Note germ cells in prophase of meiosis (arrowed). $\times 990$.

Fig. 4. Low power view of testis in Fig. 3 to show proximity of testis cord to mesonephric rete region $(\mathrm{M}) . \times 275$.

Fig. 5. Testis of XX $S x r /+$ male fetus at 16 days p.c. Note germ cells in prophase of meiosis (arrowed). $\times 990$.

Fig. 6. Lower power view of testis in Fig. 5 to show proximity of testis cord to mesonephric rete region $(\mathrm{M}) . \times 275$. 


\section{PLATE 1}
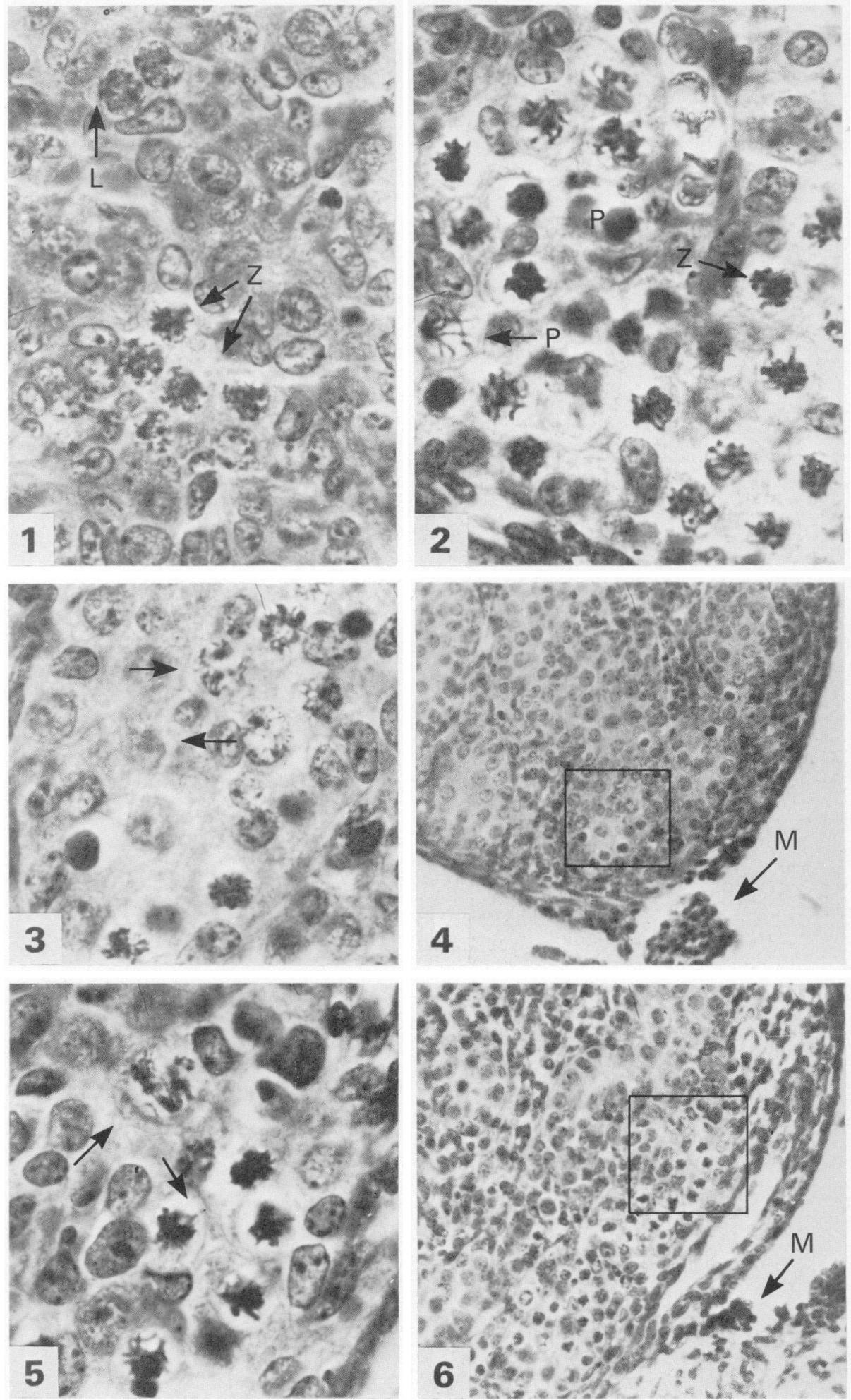

(Facing p. 464) 
Table 4. Presence of meiotic germ cells in mouse fetuses 15-16 days p.c., from XO females mated to $\mathrm{Sxr} /+$ males (Series 3)

\begin{tabular}{cccr}
\hline & & \multicolumn{2}{c}{ No. of fetuses } \\
\cline { 3 - 4 } $\begin{array}{c}\text { Genotype } \\
\text { of fetus }\end{array}$ & $\begin{array}{c}\text { Phenotypic } \\
\text { sex }\end{array}$ & $\begin{array}{c}\text { With meiotic } \\
\text { germ cells }\end{array}$ & Total \\
\hline XX $+/+$ & $\wp$ & 22 & 22 \\
XO $+/+$ & $\wp$ & 4 & 4 \\
XY + ++ or XY $S x r /+$ & $\delta$ & 0 & 31 \\
XX $S x r /+$ & $\delta$ & 9 & 10 \\
XO $S x r /+$ & $\delta$ & 0 & 5 \\
\hline
\end{tabular}

\section{Discussion}

It seems that germ cells belonging to a genetically uniform population, all $\mathrm{XX}$ in chromosome constitution, can follow either of two divergent developmental pathways in the testis of a Sex-reversed mouse. The majority follow the male pathway, undergoing mitotic arrest in the prenatal period and degenerating soon after birth, as Type A or even Type B spermatogonia (Cattanach et al., 1971). A minority, however, may follow the female pathway, and enter the prophase of meiosis in the prenatal period. Most of these probably degenerate in pachytene, as large numbers of XX germ cells undergo atresia at this stage in the normal ovary. A few survive into the post-natal period and develop into growing oocytes (McLaren, 1980). None has been seen in the adult testis, perhaps because of inadequate follicular development. The failure (Table 2) to detect meiotic germ cells in the Sex-reversed testis at the end of gestation may be accounted for by the less distinctive appearance of the oocyte nucleus at this time, the small proportion of cells that develop beyond pachytene, and the increase in size of the testis which makes the detailed examination of every tubule in serially sectioned material increasingly difficult as gestation proceeds.

The number of germ cells following the female pathway was variable, but always small. Accurate counts were not carried out, as it was judged that the results would not be sufficiently meaningful to justify the labour involved. Counts on sectioned material can only give information for one moment in time, and there was no way of knowing how soon any particular meiotic cell would degenerate, or whether other germ cells would have entered meiosis subsequent to the count.

The fact that genetically identical germ cells may follow different developmental pathways establishes that germ cell development is not autonomous, but is influenced by external factors. The spatial location of the sub-population entering meiosis before birth and thus following the female pathway, in the cords adjacent to the mesonephric rete, confirms the conclusion of Byskov \& Saxen (1976) that entry into meiosis is stimulated by a diffusible substance emanating from this region. In the absence of such stimulation, the germ cells undergo mitotic arrest and thus follow the male pathway. As distance from the rete increases, so the likelihood of prenatal entry into meiosis decline; location within a testis cord appears to shield a germ cell from stimulation with MIS, but only to a partial extent.

However, presence of MIS and location within the gonad are not the only factors that determine whether or not a germ cell enters meiosis before birth. The chromosome constitution of the germ cell itself is clearly also relevant. On an $S x r /+$ genetic background, some XX germ cells enclosed in testis cords enter meiosis, while XY and XO germ cells in the same situation have not been observed to do so. For germ cells not enclosed in testis cords, the likelihood of entering meiosis is of course higher, but the same inequalities relating to chromosome constitu- 
tion still seem to hold. XX germ cells in an ovary all enter meiosis before birth; a qualitative assessment of the ovaries of $\mathrm{XO}$ and $\mathrm{XX}$ fetuses suggests that the entry of $\mathrm{XO}$ germ cells into meiosis is either incomplete or retarded (A. McLaren \& P. S. Burgoyne, unpublished observations); XY germ cells sometimes, but not always, enter meiosis if they become excluded from a testis cord (Byskov, 1978). These relationships are summarized in Table 5. They suggest that, both inside and outside the testis cords, the germ cells with two X chromosomes (XX) are more responsive to the meiosis stimulating influence from the rete than are those with only a single $\mathrm{X}$ chromosome (XY or $\mathrm{XO}$ ).

Table 5. Meiotic status of mouse fetal germ cells, in relation to their location and sex chromosome constitution

\begin{tabular}{|c|c|c|c|c|}
\hline \multirow[b]{2}{*}{ Location } & \multirow[b]{2}{*}{$\begin{array}{l}\text { Sex chromosome } \\
\text { constitution }\end{array}$} & \multicolumn{2}{|c|}{ Germ cells } & \multirow[b]{2}{*}{ Source } \\
\hline & & $\ln _{\text {meiosis }}$ & $\begin{array}{l}\text { Not in } \\
\text { meiosis }\end{array}$ & \\
\hline \multirow[t]{3}{*}{ Inside testis cords } & $\mathrm{XX}$ & + & + & $\mathrm{XX} S x r /+$ (this paper) \\
\hline & xo & - & + & XO $S x r /+$ (this paper) \\
\hline & $X Y$ & - & + & Normal or XY $S x r /+$ testis \\
\hline \multirow[t]{3}{*}{ Not inside testis cords } & $\mathrm{XX}$ & + & - & Normal XX ovary \\
\hline & XO & + & $+?$ & $\begin{array}{l}\text { XO ovary (A. McLaren \& P.S. Burgoyne } \\
\text { unpublished observations) }\end{array}$ \\
\hline & $X Y$ & + & + & $\begin{array}{l}\text { Germ cells excluded from cords in normal } \\
\text { testis (Byskov, 1978) }\end{array}$ \\
\hline
\end{tabular}

The situation in $\mathrm{XX} / \mathrm{XY}$ chimaeric testes now becomes easier to understand. The fact that only a small number of meiotic germ cells were found in the chimaeric testes suggests that, as in the Sex-reversed testes, the concentration of MIS reached even a marginally effective level in only a few testis cords. The germ cells induced to enter meiotic prophase would have been those from the XX rather than the XY population, since the second $\mathrm{X}$ chromosome would have allowed the XX cells to respond to an MIS concentration, sub-threshold for XY cells. On the other hand, in those chimaeras that possess an ovotestis, with a disorganized cord structure, $\mathrm{XY}$ as well as $\mathrm{XX}$ germ cells would be expected to enter meiosis. Premature entry of $\mathrm{XY}$ germ cells into meiosis has been observed when the cord structure has been disrupted by transplantation of the fetal gonad and associated mesonephros under the kidney capsule (Ożdżeński, 1972), as well as in the disorganized cords of hermaphrodite gonads (Whitten, Beamer \& Byskov, 1979).

The hypothesis that fetal germ cells with two $\mathrm{X}$ chromosomes are more responsive to MIS than those with only one implies that both $\mathrm{X}$ chromosomes must be functioning at the time when the cells are responding to MIS, i.e. immediately before they are observed to enter meiosis. A recent study (M. Monk \& A. McLaren, unpublished observations) in which the ratio of the activity of the X-coded enzyme HPRT to the autosomal enzyme APRT was used as an index of $\mathrm{X}$ chromosome function has shown that this is indeed so: at $11 \frac{1}{2}$ days p.c. the ratio is similar in $\mathrm{XX}$ and $\mathrm{XY}$ germ cells, but by $12 \frac{1}{2}$ days p.c. (before any germ cells in meiotic prophase can be detected in the fetal ovary) XX germ cells show significantly higher ratios than XY germ cells, indicating that the previously inactive $\mathrm{X}$ in the $\mathrm{XX}$ chromosome set is now being expressed.

\section{References}

Burgoyne, P.S. (1978) The role of the sex chromosomes in mammalian germ cell differentiation. Annls Biol. anim. Biochim. Biophys. 18, 317-325.
Byskov, A.G. (1974) Does the rete ovarii act as a trigger for the onset of meiosis? Nature, Lond. 252, 396-397. 
Byskov, A.G. (1978) The meiosis inducing interaction between germ cells and rete cells in the fetal mouse gonad. Annls Biol. anim. Biochim. Biophys. 18, 327-334.

Byskov, A.G. \& Saxen, L. (1976) Induction of meiosis in fetal mouse testis in vitro. Devl Biol. 52, 193-200.

Cattanach, B.M., Pollard, C.E. \& Hawkes, S.G. (1971) Sex-reversed mice: $\mathrm{XX}$ and $\mathrm{XO}$ males. Cytogenetics 10, 318-337.

Evans, E.P., Burtenshaw, M.D. \& Ford, C.E. (1972) Chromosomes of mouse embryos and newborn young: preparations from membrane and tail tips. Stain Technol. 47, 229-235.

McLaren, A. (1976) Mammalian Chimaeras. Cambridge University Press.

McLaren, A. (1980) Oocytes in the testis. Nature, Lond. 283, 688-689.

McLaren, A., Chandley, A.C. \& Kofman-Alfaro, S. (1972) A study of meiotic germ cells in the gonads of foetal mouse chimaeras. J. Embryol. exp. Morph. 27, 515-524.
Mystkowska, E.T. \& Tarkowski, A.K. (1968) Observations on CBA-p/CBA-T6T6 mouse chimaeras. $J$. Embryol. exp. Morph. 20, 33-52.

Mystkowska, E.T. \& Tarkowski, A.K. (1970) Behaviour of germ cells and sexual differentiation in late embryonic and early postnatal mouse chimaeras. J. Embryol. exp. Morph. 23, 395-405.

O, W.S. \& Baker, T. G. (1976) Initiation and control of meiosis in hamster gonads in vitro. J. Reprod. Fert. 48, 399-401.

Ożdżenski, W. (1972) Differentiation of the genital ridges of mouse embryos in the kidney of adult mice. Archs Anat. microsc. Morph. exp. 61, 267-278.

Vickers, A.D. (1967) Amniotic sex chromatin and foetal sexing in the mouse. J. Reprod. Fert. 14, 503-505.

Whitten, W.K., Beamer, W.G. \& Byskov, A.G. (1979) The morphology of fetal gonads of spontaneous mouse hermaphrodites. J. Embryol. exp. Morph. 52, 63-78.

Received 14 July 1980 